\title{
乳牛の乾乳後期における第一胃内容抢よび尿性状の簡易臨床 検査所見と各種周産期疾病発生との関係
}

\section{山岸則夫 ${ }^{11}$ 李 仁昫 $^{21}$ 大星健治 ${ }^{1)}$ 安藤道雄 ${ }^{3}$ 高木光博 ${ }^{3}$ 中川 昭 ${ }^{51}$}

1)带広畜産大学大動物特殊疾病研究センター、2)带広畜産大学臨床獣医学講座、

3)宗谷南部地区農業改良普及センター、年鹿児島大学農学部、

5) あり家畜医院（北海道大樹町）

\section{Relationship between Periparturient Disorders and Simple Clinical Parameters for the Ruminal Contents and Urine during the Close-up Period in Dairy Cows}

\author{
N. Yamagishi ${ }^{1)}$ I. Lee ${ }^{2)}, \mathrm{K}$. Oboshi $^{1)}$ 、M. Ando ${ }^{3)}$, \\ M. Takagi ${ }^{4)}$ A. Nakagawa ${ }^{5}$
}

${ }^{1)}$ Research Center for Animal Hygiene and Food Safety and ${ }^{2)}$ Dept. of Vet. Clin. Sci., Obihiro University of Agriculture and Veterinary Medicine, ${ }^{3}$ Souya Southern Region Agricultural Improvement and Extension Center, ${ }^{4)}$ Fac. Of Agric, Kagoshima University,

${ }^{5)}$ Akira Veterinary Hospital (Taiki、Hokkaido)

\begin{abstract}
要 約 1 牛群で 2 年間に分婏したホルスタイン経産牛のベ160頭に対し、乾乳後期に、毎週 1 回一 定時刻に臨床検查（第一胃の内容量および性状、尿 $\mathrm{pH}$ およびヶトン体濃度のスコア評価）を行い、そ れらの所見と周産期疾病との関倸を検討した。さらに、血液生化学検査を行い、上記の臨床検査の有用 性を判断した。周産期疾病は 160 頭中 64 頭に発生し、その内訳はケトーシス $(\mathrm{n}=27)$ 、第四胃変位 $(\mathrm{n}=$ 17)、産裖期子宮疾患（ $\mathrm{n}=12 ）$ ならび乳熱（ $\mathrm{n}=8 ）$ であった。周産期疾病の罹患牛では、分娩 1 週前 に分婏 2 週間前に比べて第一胃の内容量と尿 $\mathrm{pH}$ のコアが有意な低值を示した。血液検査所見におい て、周産期疾病の罪患牛では、健康牛に比べて血清FFA濃度の高值やBUN、T-Cho、Glu、iPとMg濃 度の低值傾向が認められ、エネルギーバランスの低下が示唆された。乾乳後期における定期的な臨床検 查によって、周産期疾病の発生を予測することは可能と思われた。 ——ーワード：乾乳後期、同産期疾病、第一胃、乳牛、尿検査
\end{abstract}


ABSTRACT Data from 160 multiparous Holstein cows during the close-up period were collected for the evaluation of the clinical parameters (the volume and nature of the ruminal ingesta, urine $\mathrm{pH}$ and keton body) to predict periparturient diseases. Blood chemistry was also analyzed to assess feasibility of practical application of these parameters. 64 of the 160 cows experienced periprturient diseases such as ketosis $(n=27)$, abomasum displacement $(n=17)$, puerperal uterus diseases $(n=12)$ and milk fever $(n=8)$. The scores for the volume of the ruminal ingesta and urinary $\mathrm{pH}$ significantly decreased from 2-week to 1-week prepartum in the cows having periparturient diseases. The blood chemistry profile revealed high concentration of FFA and low levels of BUN, T-Cho, Glu, iP and $\mathrm{Mg}$ in the cows with periparturient diseases, suggesting disrupted energy balance during the close-up period. Our data suggested that these clinical parameters in cows during the close-up period were useful to predict the periparturient diseases, if examined routinely.

Key Words : close-up period, periparturient diseases, rumen, dairy cows, urinalysis

Jpn. J. Vet. Clinics 27(1):13-19,2004

\section{緒 言}

乳牛におけるケトーシス、第匹胃変位、産裖期の子宮 疾患、乳熱などの周産期疾病の発生は乾乳期からの飼養 管理の失宜と関係が深く、この時期の栄養状態や乾物摄 取量の安定化を計ることが疾病予防の基本である $[3$, $8,10,17]$ 。その上で、乾乳期において、各個体ごとに 疾病の予兆を摘発できれば、いっそう效果的な予防対策 が実施可能となる [16]。このような観点から、我が国 では、血液代謝プロファイルテストに関する研究が数々 なされており、いずれも一定の成果を収めている $[12$, 13，16]。しかし、多くの酪農家にとっては、高頻度に 血液代謝プロファイルテストを導入することは経済的に 困難である。したがって、日常的な牛群管理において、 安価かつ簡便で、その場で判定でき、しかも誰でも実施 可能な検査手段があれば有用と思われる。そこで、本研 究では、乾乳後期の乳牛に対して第一胃内容と尿性状の 簡易臨床検查を行い、周産期疾病の予兆発見の観点加 、 その有用性について検討した。

\section{材料および方法}

供試牛群：北海道十勝管内で搾乳牛約 100 頭を飼養する 一般酪農家の牛群を対象にした。搾乳牛は牛舎内の夕イ ストールにて飼養され、毎日朝夕搾乳された。乳牛は分 婏前約60日方乾乳とし、分婏予定日 2 一 週間前まで 屋外のパドックにて飼養された（乾乳前期）。分婏予定 日 $2-3$ 总間以内（乾乳後期）は、屋外の屋根付きペン にて飼養された。同ペンにて分婏後、直ちに子牛は離さ
れ、その後搾乳牛舎内に慗留された。飼料として定期的 に実施される粗飼料成分分析の結果をもとに設計した泌 乳期、乾乳前期および乾乳後期用の各TMRが毎日作成 され、1日1回、一定の時間带（午前 8 時から10時）に 給慨された。

供試牛、簡易臨床検査および採血：2001年 4 月から 2003年 3 月までに分娭した経産乳牛107頭、のべ160頭の 乾乳後期牛群を対象とし、これらの乳牛を診療記録をも とに、乾乳後期から分姢後 3 週間までの間に周産期疾病 の発生を認めなかった健康牛と、ケトーシス、第四胃変 位、産裖期子宮疾患、乳熱などの各周産期疾病の罹患牛 とに区分した（表 1 ）。週 1 回の定期往診時の一定時間 带 (午後 $2 \sim 3$ 時) に、第一胃内容と尿性状の簡易検查 ならびに採血を行った。本牛群では毎月一回の牛群検定 にあわせて、Fergusonらの方法［6] に準じてボディ コンディションスコア（BCS）を測定していた。したがっ て、本研究では、研究期間中に分婏した経産乳牛の月齿、 産次、前期空胎日数、前乳期305日実乳量、分婏前 1 2 ヶ月ならびに分婏前1 ケ月以内のBCSなどの背景情報 についても整理した。

第一胃内容および尿性状の簡易臨床検査：第一胃の簡 易臨床検査は、我々が既に報告した左膁部触診による方 法 [18］によって、第一胃内容量（RV）と第一胃内容 性状（RC）を評価した。すなわち、RVは腰椎横突起か ら下腹にかけての左膁部の触診による第一胃の充満程度 を、スコア 0 （腹側 $1 / 2$ 以下）、 1 (腹側 $1 / 2$ 以上、 $2 / 3$ 以 下)、2（腹側 $2 / 3$ 以上）の 3 段階に、また、RCはスコ 


\begin{tabular}{|c|c|c|c|}
\hline \multirow{2}{*}{ 周産期疾病 } & \multirow{2}{*}{ 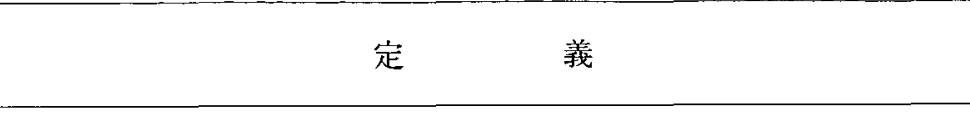 } & \multicolumn{2}{|c|}{ 発生状況 } \\
\hline & & 頭数 & 分婏後日数 \\
\hline 健康牛 & $\begin{array}{l}\text { 畜主の観察および獣医師の定期検診時において、食欲低下などの異 } \\
\text { 常所見を認めないもの }\end{array}$ & 96 & \\
\hline ケトーシス & 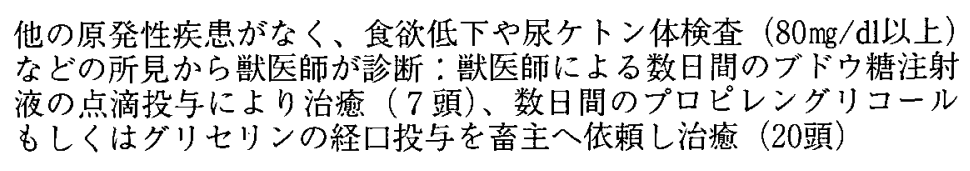 & 27 & $-1 \sim 18$ \\
\hline 第四胃変位 & 獣医師が䛦断：外科的整復手術を実施し治癒 & 17 & $4 \sim 17$ \\
\hline 産裖期子宮疾患 & $\begin{array}{l}\text { 難産や胎盤停滞に起因した、発熱や食欲不振などの所見から産裖熱 } \\
\text { と獸医師が診断：治療によって治癒 }\end{array}$ & 12 & $1 \sim 8$ \\
\hline 乳熱 & $\begin{array}{l}\text { 起立不能、弛緩麻痺、体温低下などの所見から獣医師が診断：1〜 } \\
2 \text { 回のカルジウム剤の静脈内投与により治瘉 }\end{array}$ & 8 & $0 \sim 16$ \\
\hline
\end{tabular}

ア0（第一胃内容は均一でルーメンマットの形成を認め ない)、1（第一胃内容は 2 層構造だが、ルーメンマッ 卜は薄く脆弱)、2（第一胃内容は 2 層構造で、しっか りと硬いルーメンマットが形成）の3段階にスコア化し た。尿性状の簡易臨床検査は、N-マルティスティック ス (バイエルメディカル、東京) を用いて尿 $\mathrm{pH}(\mathrm{U}-\mathrm{pH})$ とケトン体濃度（U-Ket）を定量し、U-pHは5.0〜8.5ま で0.5間隔の 7 段階に、U-Ketはスコア 0 （尿中濃度 $4 \mathrm{mg}$ $/ \mathrm{dl}$ 以 $) 、 1 \quad(5 \sim 14 \mathrm{mg} / \mathrm{dl}) 、 2 \quad(15 \sim 39 \mathrm{mg} / \mathrm{dl}) 、 3(40$ $\sim 79 \mathrm{mg} / \mathrm{dl}) 、 4 \quad(80 \sim 159 \mathrm{mg} / \mathrm{dl})$ 扝よび $5 \quad(160 \mathrm{mg} / \mathrm{dl}$ 以 上）の 5 段階にスコア化した。

血液生化学検查：正中尾静脈もしくは同動脈から、血 清分離用真空採血菅（テルモ；東京）抢よび血糖測定用 フッ化ナトリウム加真空採血菅（テルモ；東京）を用い て採血した。採取血液は直ちに氷水中に入れて 3 時間以 内に大学内へ搬入し、血清および血漿を分離後、血液自 動分析装置 (TBA-30R：東芝ラボメディカル；東京） による血液生化学検查に供した。測定項目は、アスパラ ギン酸アミノトランスフェラーゼ（AST）、血中尿素窒 素 (BUN)、総コレステロール（T-Cho）、遊離脂肪酸

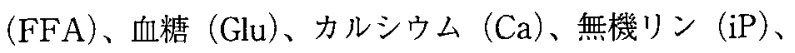
マグネシウム $(\mathrm{Mg})$ の 8 項目とした。

統計好理：月齢や乳量などの背景情報については、健 康牛と周産期疾病の各発生牛の各項目に関してKruskalWall-is検定を行い、いずれかの群間に有意差ありと判定 された場合、Mann-Whitney検定によって各周産期疾病 発生牛と健康牛との差を比較した。

第一胃内容掞よび尿の簡易臨床検查所見ならびに血液 生化学検查成績の継時推移の解析には、乾乳後期を実際 の分婏日を基準に分婏 2 週前（分娩 8～14日前）と分婏 1 週前（分婏 1 ～ 7 日前）の 2 つに区分した。第一胃内 容と尿性状の簡易臨床検査所見では、まず、健康牛 $(\mathrm{n}=96)$ と周産期疾病罹患牛（ $\mathrm{n}=64 ） の 2$ 群の乾乳後 期の各時期における差についてMann-Whitney検定にて 比較した。さらに、乾乳後期の各時期の簡易臨床検査と 血液生化学検査のすべて所見について、健康牛 $(\mathrm{n}=96)$ とケトーシス $(n=27) 、$ 第四胃変位 $(n=17)$ 、産裖期子 宮疾患 $(n=12)$ 、乳熱 $(n=8)$ の各罹患牛の 5 群に区 分してKruskal-Wallis検定とMann-Whitney検定を用い て解析し、各周産期疾病と健康牛との差をそれぞれ検定 した。

第一胃内容および尿の簡易臨床検査所見ならびに血液 生化学検查成績の周産期疾病発生への影響を判定するた めに、健康牛には 1、いずれかの周産期疾病の罹患牛に は0のダミー変数を与え、各周産期疾病ごとに各検查成 績との相関性の強さをSpearman順位相関係数検定にて 評価した。

統計処理にはStatView J-4.5 software (Abacus Concept, Inc. ； USA）を用い、 $\mathrm{P}<0.05$ の場合に有意 差ありと判定した。

\section{成 績}

背景情報：乳熱罹患牛は健康牛に比べ有意に月齢が高 かった（表 2)。ケトーシス罹患牛では、前期空胎日数 が有意に長く、分娩 1 - 2 月でのBCSが有意に高かっ た。

簡易臨床検查および血液生化学検查所見の継時的推移： 健康牛と周産期疾病罹患牛の 2 群について簡易臨床検査 所見の推移を比較したところ、周産期疾病罹患牛のRV およびU-pHの各スコアは分婏 1 週前で分婏 2 週間前に 比べて有意に低值を示した（図 1 )。健康牛と周産期疾 病の各槛患牛の 5 群に区分して簡易臨床検査拉よび血液 生化学検查所見の推移を比較したところ、第四胃変位罹 患牛では分娩 2 週前の $\mathrm{Mg}$ 值と分婏 1 週前の血清 $\mathrm{Ca}$ 值が、 
表 2 健康牛と各周産期疾病の罹患牛における背景情報

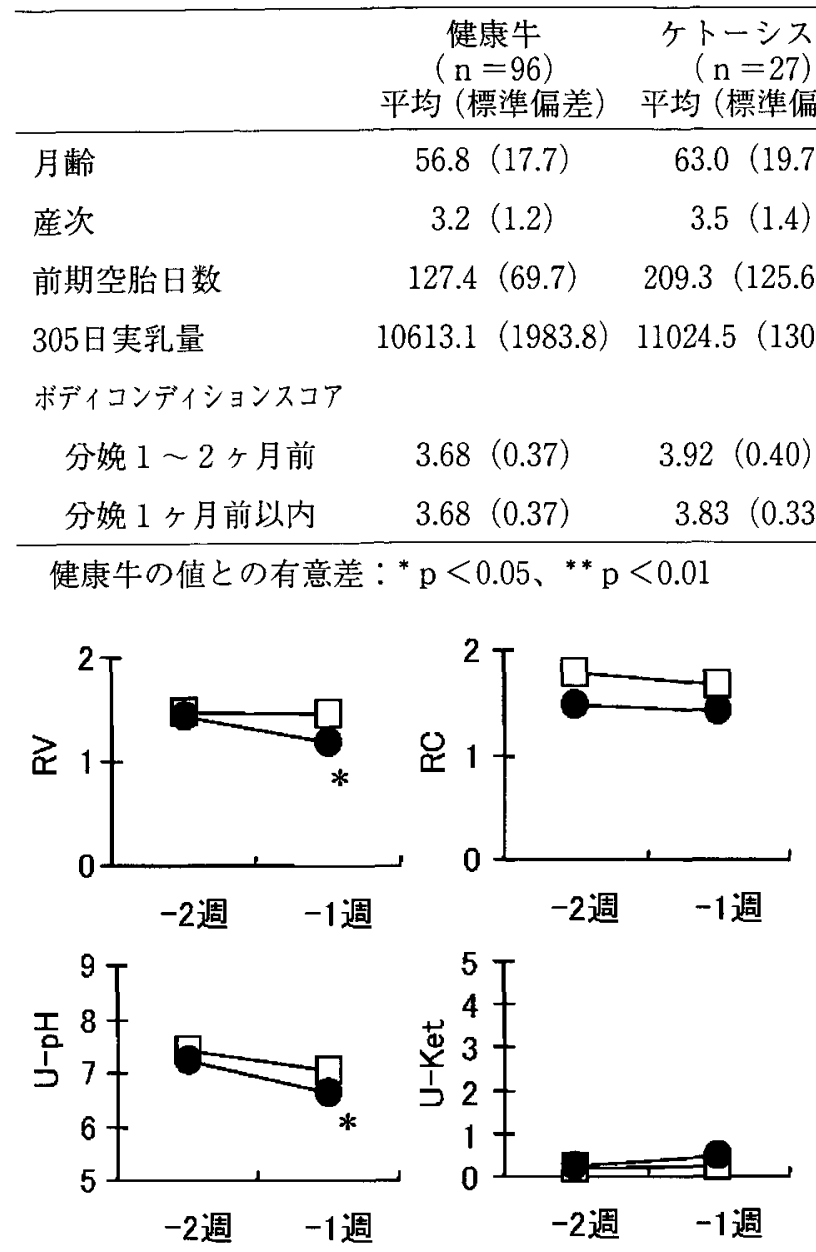

図 1 健康牛 $(\square ; n=96)$ と周産期疾病䍜患牛 $(0 ; n=$ 64）における乾乳後期の第一胃内容および尿性状 の簡易臨床検査成績（平均値）の推移

$\mathrm{RV}$ : 第一胃内容量、 $\mathrm{RC}$ : 第一胃内容性状、U-pH：尿 pH、U-Ket：尿ケトン体濃度、 -2 週：分婏 2 週前、 -1 週：分娭 1 週前

同時期の健康牛の值との有意差 : ${ }^{*} \mathrm{P}<0.05$

産裖期子宮疾患罹患牛では分娩 2 週前の $\mathrm{Mg}$ 值がそれぞ れ健康牛に比べて有意な低值を示した（表 3 ）。

乾乳後期における簡易臨床検査および血液生化学検査 所見と各周産期疾病との相関性 : 乾乳後期 $の$ 簡易臨床検 査所見において、ケトーシス罹患牛ではRCのスコアが、 産裖期子宮疾患罹患牛ではU-pHが、乳熱罹患牛ではRV とU-Ketのスコアが有意な負の相関を示した（表 4 ）。 血液生化学検查所見では、ケトーシスおよび第四胃変位 䍜患牛では共通して、BUNとMg值が有意な負の相関を、 FFA濃度が正の相関を示した。産裖期子宮疾患䍜患牛 では、BUNとMg值が負の相関を、FFA濃度が有意な正 の相関を示した。乳熱罹患牛では、T-ChoとiP值が有意 な負の相関を示した。

考 察

牛では左膁部の腰椎横突起から下腹部までの範囲を力 強く触診 (external ruminal palpation) することによっ て、第一胃内容の量や性状、さらに発酵状況に関する情 報が得られることが知られている $[2,7,15]$ 。本法は 採食量の測定が困難である一般の臨床現場でも、その客 観的評価が可能となり、有用な臨床検査手段になると思 われる。妊娠末期の乳牛では、子宮は第一胃腹囊の下に 滑り込み、第一胃の容量は三分の一程度まで減少する [9] と言われている。さらに、周産期疾病罹患牛では、 乾乳期の乾物摄取量は健康牛より18\%減少する [20] こ とが知られている。したがって、我々は乾乳後期の乳牛 を対象とし今回行った第一胃内容の臨床簡易検査によっ て周産期疾病槛患牛の採食量減少を察知し、周産期疾病 の予測に役立てたいと考えた。その結果、健康牛と周産 期疾病罹患牛の 2 群の比較では、周産期疾病罹患牛で分 婏1週前にRVスコアの低下が観察された（図 1)。さら に、疾病別に相関関係を解析すると、乳熱执よびケトー シスの罹患牛においてRVとRCのスコアはそれぞれ負の 相関を示した（表 4$)$ 。したがって、第一胃内容の簡易 臨床検査によって周産期疾病の発生をある程度事前予測 することは可能と思われた。

尿試験紙を用いた尿性状の簡易臨床検査も、臨床現場 では有用な手法と考えられる。本研究では、U-Ketはい ずれの周産期疾病とも関係を見出せなかった。しかし、 U-pHでは、その継時的推移において周産期疾病罹患牛 は健康牛に比べて分娩 1 週前に低く、周産期疾病との相 関性の解析では、産裖期子宮疾患において有意な負の相 関を示した。産裖期子宮疾患の罹患牛においてのみU-p Hが低下した理由は定かでないが、本研究の場合には、 座裖期子宮疾患罹患牛で血清FFA濃度における正の相 関やGluとMg值における負の相関が見られたことから、 
表 3 健康牛と各周産期疾病の罹患牛における第一胃内容と尿の簡易臨床検查所見と血液生化学検査所見

\begin{tabular}{|c|c|c|c|c|c|c|c|c|c|c|c|}
\hline \multirow{2}{*}{\multicolumn{2}{|c|}{ 項目 (単位) }} & \multicolumn{5}{|c|}{ 分婏 2 週前 } & \multicolumn{5}{|c|}{ 分婏 1 週前 } \\
\hline & & 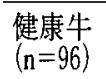 & $\begin{array}{l}\text { ケトーシス牪 } \\
(\mathrm{n}=27)\end{array}$ & $\begin{array}{l}\text { 第四胃変位牛 } \\
(\mathrm{n}=17)\end{array}$ & 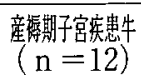 & $\begin{array}{l}\text { 乳熱牛 } \\
(\mathrm{n}=8)\end{array}$ & $\begin{array}{l}\text { 健康牛 } \\
(\mathrm{n}=96)\end{array}$ & $\begin{array}{l}\text { ケトーシス件 } \\
(\mathrm{n}=27)\end{array}$ & $\begin{array}{l}\text { 第四胃変位牛 } \\
(\mathrm{n}=17)\end{array}$ & $\begin{array}{l}\text { 産标期子宮宛患牛 } \\
(\mathrm{n}=12)\end{array}$ & $\begin{array}{l}\text { 乳熱牛 } \\
(\mathrm{n}=8)\end{array}$ \\
\hline \multicolumn{12}{|c|}{ 第一胃内容と尿の簡易臨床検査 $\left.{ }^{1}\right)$} \\
\hline RV & 平均値 & 1.5 & 1.4 & 1.5 & 1.5 & 1.3 & 1.5 & 1.2 & 1.1 & 1.3 & 1.2 \\
\hline $\mathrm{RC}$ & 平均值 & 1.8 & 1.3 & 1.4 & 2.0 & 2.0 & 1.7 & 1.3 & 1.6 & 1. & 1.5 \\
\hline U-pH & 平均值 & 7.4 & 7.0 & 7.6 & 6.5 & 7.0 & 7.0 & 6.8 & 6.6 & 6.3 & 6.2 \\
\hline U-Ket & 平均値 & 0.2 & 0.4 & 0.2 & 0 & 0 & 0.2 & 0.6 & 0.4 & 0 & 0.5 \\
\hline \multicolumn{12}{|l|}{ 血液生化学検査 } \\
\hline \multirow{2}{*}{\multicolumn{2}{|c|}{$\begin{array}{r}\mathrm{AST}(\mathrm{IU} / \mathrm{L}) \text { 平均值 } \\
\text { (標準偏差) }\end{array}$}} & 59.6 & 55.9 & 59.9 & 57.8 & 64.7 & 62.8 & & 61.3 & 78.0 & 55.3 \\
\hline & & $(9.7)$ & (11.5) & $(11.8)$ & $(9.4)$ & (15.5) & $(10.3)$ & (19.6) & (9.5) & $(41.4)$ & $(8.8)$ \\
\hline \multirow{2}{*}{\multicolumn{2}{|c|}{$\begin{array}{r}\mathrm{BUN}(\mathrm{mg} / \mathrm{dl}) \text { 平均値 } \\
\text { (標準偏差) }\end{array}$}} & 9.2 & 6.2 & 6.6 & 11.0 & 8.7 & 9.7 & 8.0 & 8.3 & 9.9 & 5.7 \\
\hline & & $(3.4)$ & $(2.6)$ & (3.6) & (3.8) & (1.4) & (3.7) & $(3.6)$ & (3.6) & (3.9) & (1.8) \\
\hline \multirow{2}{*}{ T-Cho (mg/dl } & 平均值 & 100.1 & 89.3 & 94.3 & 99.5 & 88.7 & 85.3 & 84.8 & 79.8 & 108.4 & 66.5 \\
\hline & 準偏差) & $(24.2)$ & $(13.0)$ & (12.9) & $(19.6)$ & $(23.2)$ & $(23.4)$ & $(24.5)$ & (13.7) & $(41.8)$ & (8.9) \\
\hline \multirow{2}{*}{\multicolumn{2}{|c|}{$\begin{array}{r}\mathrm{FFA}(\mathrm{mEq} / \mathrm{L}) \text { 平均值 } \\
\text { (標準偏差) }\end{array}$}} & 0.247 & 0.355 & 0.323 & 0.259 & 0.202 & 0.347 & 0.418 & 0.469 & 0.722 & 0.274 \\
\hline & & $(0.126)$ & $(0.297)$ & $(0.257)$ & $(0.141)$ & $(0.136)$ & $(0.204)$ & $(0.160)$ & $(0.226)$ & $(0.239)$ & $(0.165)$ \\
\hline \multirow{2}{*}{ Glu (mg/dl) } & 平均值 & 63.1 & 60.6 & 60.0 & 59.0 & 65.5 & 61.3 & 60.9 & 61.8 & 38.0 & 58.0 \\
\hline & 準偏差) & (4.8) & $(6.7)$ & (4.5) & $(7.8)$ & (3.5) & (7.5) & $(7.0)$ & (12.3) & (11.5) & (5.7) \\
\hline \multirow{2}{*}{$\mathrm{Ca}(\mathrm{mg} / \mathrm{dl})$} & 平均值 & 9.5 & 9.3 & 9.4 & 9.4 & 9.6 & 9.4 & 9.5 & $8.8^{* *}$ & 9.0 & 9.5 \\
\hline & 潐偏差) & $(0.6)$ & $(0.5)$ & $(0.4)$ & $(0.6)$ & $(0.9)$ & $(0.7)$ & $(0.5)$ & $(0.7)$ & $(0.4)$ & $(0.6)$ \\
\hline \multirow{2}{*}{$\mathrm{iP}(\mathrm{mg} / \mathrm{dl})$} & 平均値 & 6.1 & 5.6 & 5.9 & 6.0 & 5.3 & 6.1 & 5.8 & 5.7 & 5.2 & 5.4 \\
\hline & 準偏差) & (1.1) & $(0.8)$ & $(0.9)$ & (1.5) & $(0.9)$ & (1.2) & $(0.8)$ & $(0.9)$ & (1.3) & $(0.5)$ \\
\hline \multirow{2}{*}{$\mathrm{Mg}(\mathrm{mg} / \mathrm{dl})_{\text {(標 }}$} & 平均値 & 2.4 & 2.2 & $2.0^{*}$ & $2.0^{*}$ & 2.0 & 2.2 & 2.1 & 1.9 & 1.7 & 2.0 \\
\hline & 準偏差) & $(0.5)$ & $(0.4)$ & $(0.3)$ & $(0.2)$ & $(0.4)$ & $(0.4)$ & $(0.4)$ & $(0.4)$ & $(0.1)$ & $(0.4)$ \\
\hline
\end{tabular}

1)各項目のスコアは離散変数であるので, 平均值のみを示す. $\mathrm{RV}$ ：第一男内容量, $\mathrm{RM}$ ：第一胃内容性状, U-pH : 尿pH, U-Ket：尿中ケトン体濃度. 同時期の健康牛の值との有意差: ${ }^{*} \mathrm{P}<0.05,{ }^{*}{ }^{*} \mathrm{P}<0.01$.

表 4 各周産期疾病と各種検査成績との相関係数

\begin{tabular}{|c|c|c|c|c|c|}
\hline 項 & 目 & ケトーシス & 第四胃変位 & 産裖期子宮疾患牛 & 乳熱 \\
\hline \multicolumn{6}{|c|}{ 第一胃内容と尿の臨床簡易検査 ${ }^{11}$} \\
\hline $\mathrm{RV}$ & & -0.120 & -0.061 & -0.075 & $-0.187^{*}$ \\
\hline $\mathrm{RC}$ & & $-0.201^{*}$ & -0.137 & -0.050 & 0.016 \\
\hline U-pH & & -0.085 & -0.041 & $-0.183^{*}$ & $-0.184^{*}$ \\
\hline U-Ket & & 0.085 & 0.013 & -0.075 & 0.025 \\
\hline \multicolumn{6}{|c|}{ 血液生化学検査 } \\
\hline AST & & 0.043 & -0.066 & -0.011 & -0.095 \\
\hline BUN & & $-0.282^{* *}$ & -0.203 & 0.104 & -0.120 \\
\hline T-Cho & & -0.117 & -0.096 & 0.093 & $-0.177^{*}$ \\
\hline FFA & & $0.200^{*}$ & $0.178^{*}$ & $0.214^{*}$ & -0.125 \\
\hline Glu & & -0.095 & -0.063 & $-0.263^{* *}$ & -0.013 \\
\hline $\mathrm{Ca}$ & & 0.052 & -0.141 & -0.155 & 0.024 \\
\hline iP & & -0.136 & -0.139 & -0.131 & $-0.189^{*}$ \\
\hline $\mathrm{Mg}$ & & $-0.177^{*}$ & $-0.264^{* *}$ & $-0.264^{* *}$ & -0.152 \\
\hline
\end{tabular}

${ }^{11} \mathrm{RV}$ : 第一胃内容量, RM：第一胃内容性状, U-pH：尿pH，U-Ket：尿中ケトン体温度.

有意な相関関係: ${ }^{*} \mathrm{p}<0.05 、{ }^{* *} \mathrm{p}<0.01$.

エネルギーバランスの低下による代謝性アシドーシスも＼cjkstart言及し、Drackley [3] は分娩前 7 日以内にFFAが高

想定される。

乾乳後期の血液性状と周産期疾病との間には関係があ るとの報告は多い。Kida [12] は乾乳期のアルブミン、 T-Cho、Mg值が低く、FFA濃度が高い牛群では周産期 疾病が多いと報告している。佐藤ら [16] は乾乳後期の 值を示した乳牛ではケトーシス、第四胃変位、もしくは 胎盤停滞を発症すると述べている。本研究では、第四胃 変位と産褿期子宮疾患の䍜患牛にて血清CaおよびMg濃 度が低值を示した。さらに、Spearman順位相関係数検 定では、ケトーシスおよび第四胃変位罹患牛でBUNと 高FFAと低Ca值が周産期疾病の発生に関連することを $\mathrm{Mg}$ 值が負のおよびFFAが正の相関を、産褲期子宮疾患 
ではFFAが正の相関およびGluと Mg值が負の相関を、 さらに乳熱罹患牛ではT-ChoとiP值が負の相関を示した。 一般に、血清BUNならびにMg濃度は、それぞれ、エネ ルギーとタンパクの摂取 [11] ならびに乾物㠌取量 [12]に関係するとされている。血清T-Cho濃度は線維 の摂取 [4] と関連し、さらに肝機能に伴うエネルギー 代謝を反映する $[13,19]$ 。また、血清FFAは負のエネ ルギーバランスによる体脂肪動員によって上昇し $[3$ ， 10]、血清中のCaやiPはタンパクやエネルギーの摂取を 反映する $[11,13]$ ことが示されている。したがって、 本研究における血液生化学検査所見は乾乳後期における 採食量の低下を反映したものであり、Zametら [20] が 報告したように、採食量の低下は周産期疾病発生の誘引 の一つになると考えられた。

ケトーシス罹患牛では乾乳期のBCSが高く、前期空胎 日数が延長していた。その理由として、本牛群では全て の泌乳牛は泌乳期や乳量に関係なく泌乳最盛期を想定し たエネルギー価の飼料が給飭されていたので、空胎日数 の延長によって必乳後期に過肥になり、さらにそのまま 乾乳期を迎えることで乾物搨取量の低下から体脂肪の動 員を招き $[1 ， 17]$ 、ケトーシスに至ったと考えられた。 また、本研究においても乳熱罹患牛は高齢であり、これ までの報告 $[5,14]$ と一致していた。

乾乳後期の乳牛を対象とした第一胃内容と尿性状の簡 易臨床検查を定期的に活用することによって、周産期疾 病の事前予測はある程度可能と考えられた。とくに、高 齢で、前期空胎日数が延長LBCSが高い個体では、RV やU-pHのスコアの低下によって、ケトーシスや乳熱の 発症牛を事前に摘発できると考えられた。しかしながら、 いっそう精度の高い予測には、時々、定期的な血液生化 学検査を実施し、牛群の栄養状態を多角的に把握するこ とが望ましいと思わ扎る

\section{謝 辞}

本研究に際し、終始快くご協力を頂いた（有）サクセ ス・ファームの宿田成宏氏ならびに従業員の皆様に深謝 する。なお、本研究の一部は文部科学省「21世紀COE プログラム」補助金 $(A-1)$ によって行われた。

\section{引用文献}

1. Busato, A., Faissler, D., Kupfer, U. and Blum, J. W. (2002). Body condition score in dairy cows: associations with metabolic and endocrine changes in healthy dairy cows. J. Vet. Med., A49: 455-460.
2. Constable, P. D. (1993). Introduction to the ruminant forestomach. In: Current Veterinary Therapy 3: Food Animal Practice (Howard, J. L. ed), 706711. W. B. Saunders, Philadelphia.

3. Drackley, J. K. (1999). Biology of dairy cows during the transition period: the final frontier? J. Dairy Sci. 82: 2259-2273.

4. Eicher, R., Liesegang, A., Bouchard, E. and Tremblay, A. (1999). Effects of cow-specific factor and feeding frequency of concentrate on diurnal variations of blood metabolites in dairy cows. Am. J. Vet. Res. 60: 1493-1499.

5. Erb, H. N. and Grohn, Y. T. (1988). Epidemiology of metabolic disorders in the periparturient dairy cows. J. Dairy Sci. 71: 2557-2571.

6. Ferguson, J. D., Galligan, D. T. and Thomsen, N. (1994). Principal descriptions of body condition score in Holstein cows. J. Dairy Sci. 77: 2695-2703.

7. Garry, F. (1990). Evaluating motility disorders of the bovine forestomach. Vet. Med. 85: 634-642.

8. Gerloff, B. J., Herdt, T. H. and Emery, R. S. (1986). Relationship of hepatic lipidosis to health and performance in dairy cattle. J. Am. Vet. Med. Assoc. 188: $845-850$.

9. Goff, J. P. and Horst, R. L. (1997). Physiological changes at parturition and their relationship to metabolic disorders. J. Dairy Sci. 80: 1260-1268.

10. Grummer, R. R. (1995). Impact of changes in organic nutrient metabolism on feeding the transition dairy cow. J. Animal Sci. 73: 2820-2833.

11. Ingraham, R. H. and Kappel, L. C. (1988). Metabolic profiling testing. Vet. Clin. North Am. Food Anim. Pract. 4: 391-411.

12. Kida, K. (2002). Use of every ten-day criteria for metabolic profile test after calving and dry off in dairy herds. J. Vet. Med. Sci. 64: 1003-1010.

13. Kronfeld, D. S., Donoghue, S., Copp, R. L., Stearns, F. M. and Engle, R. H. (1982). Nutritional status of dairy cows indicated by analysis of blood. J. Dairy Sci. 65: 1925-1933.

14. Kume, S., Nonaka, K. and Oshita, T. (2003). Relationship between parity and mineral status in dairy cows during the periparturient period. Anim. Sci. J. 74: 211-215. 
15. Leek, B. F. (1983). Clinical diseases of the rumen: A physiologist's view. Vet. Rec. 113: 10-14.

16. 佐藤繁、小野秀弥、植松正巳、畠山直一郎、角田元 成（2003）。周産期疾患の発症乳牛における乾乳期の 血中成分. 家畜臨床誌 26: 21-26.

17. Shever, R. D. (1997). Nutritional risk factors in the etiology of left displaced abomasums in dairy cows: A review. J. Dairy Sci. 80: 2449-2453.

18. 山岸則夫、大星健治、李仁炣、高木光博、安藤道雄、 中川昭 (2003). 分婏後の乳牛に対する大量溶液の強 制経口投与がその後の第一胃内容量と血液生化学性状 へ及ぼす影響. 臨床獣医 21: 32-35.

19. 山田恭嗣、中尾敏彦、園中篤、南繁、宮野正章、中 尾茂、森好政晴、河田啓一郎（1994）。乳牛の栄養状 態と周産期疾病扝よび受胎成績. 日獣会誌. 47: 322326.

20. Zamet, C. N., Colenbrander, V. F., Callenhan, C. J., Chew, B. P., Erb, R. E. and Moeller, N. J. (1979). Variables associated with peripartum traits in dairy cows. I. Effect of dietary forages and disorders on voluntary intake of feed, body weight and milk yield. Theriogenology. 11: 229-224. 